\title{
Reduced mobility is associated with compensatory feeding and increased diet breadth of marine crabs
}

\author{
John J. Stachowicz*, Mark Hay** \\ University of North Carolina at Chapel Hill, Institute of Marine Sciences, Morehead City, North Carolina 28557, USA
}

\begin{abstract}
Direct effects of predation have been widely recognized as important in affecting prey population dynamics and evolution. However, less attention has been devoted to the consequences of indirect effects of predators on prey behavior. For example, to avoid predation many animals restrict their activities to physical refugia and adopt low-mobility lifestyles, yet the consequences of these antipredator behaviors for foraging and diet selection are relatively unknown. In this study we examine the relationships between mobility, feeding preferences, and compensatory feeding for 3 species of marine decapod crabs feeding on seaweeds in North Carolina, USA. Low mobility and high site fidelity of crabs were associated with a broad, non-selective diet and compensatory feeding. The majid Mithrax forceps exhibited the lowest mobility, highest site fidelity, and least selective diet of the 3 species, whereas another majid Libinia dubia was intermediate in both mobility and selectivity, and the xanthid

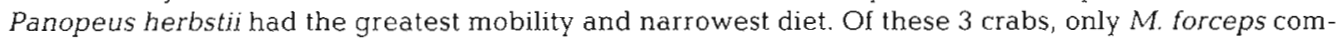
pensated for low food quality by increasing consumption rates in single food-species feeding assays. This may be because $M$. forceps is resistant to (or tolerant of) seaweed chemical defenses, while other crab species are not. The ability to consume, and presumably subsist on, a wide variety of potential foods including those defended from more mobile consumers may facilitate a low-mobility lifestyle, allowing the crab to minimize movement and reduce exposure to predators. Low mobility and high sitefidelity may thus facilitate the formation and use of associational refuges with sessile benthic organisms that are resistant to predators; these associations can have important community and ecosystem-wide consequences.
\end{abstract}

KEY WORDS: Associational refuge $\cdot$ Compensatory feeding $\cdot$ Crabs $\cdot$ Diet breadth $\cdot$ Mobility

\section{INTRODUCTION}

Predation pressure on small marine invertebrates like crabs, amphipods and gastropods may be intense and can limit the distribution and abundance of these animals in the field (Randall 1967, van Dolah 1978, Nelson 1979, Stoner 1979, Heck \& Wilson 1987, Duffy \& Hay 1994, Stachowicz \& Hay 1996). However, in addition to the direct effects of consumption, predators may indirectly affect prey population dynamics and evolution by selecting for anti-predator behaviors such as decreased mobility. Many otherwise mobile marine

\section{Present addresses:}

- University of Connecticut, Department of Marine Sciences, 1084 Shennecossett Rd., Groton, Connecticut 06340, USA.

E-mail: jstach@uconnvm.uconn.edu

- School of Biology, Georgia Institute of Technology, Atlanta, Georgia 30332-0230, USA organisms adopt sedentary lifestyles in refuges from predation (e.g. Steneck 1982, Coen 1988a, Hay et al. 1989, Duffy \& Hay 1994, Littler et al. 1995, Stachowicz \& Hay 1996, 1999a). Because predation pressure in some habitats may be predictably high, and because the cost of gathering information about predation risk may be great, some animals spend the bulk of their lives in these refuges (Sih 1987), potentially limiting the kinds and numbers of available foods to which they have access. To ensure an adequate and reliable food supply, some consumers specialize on one type of food (often an alga) and live directly on it, using it as both food and shelter (Hay et al. 1989, 1990a,b, Pennings 1990, Faulkner 1992). However, this lifestyle may not be feasible for animals that have high consumption rates which preclude specialization on an individual plant or that are too large for an alga to provide adequate shelter (e.g. Pennings 1990). As a consequence, 
larger grazers (such as many decapod crabs) that have low mobility may be driven to adopt a broader diet to decrease foraging time and minimize the risk of predation. Thus, these species may be better able to consume whatever foods are nearby, including those with morphological or chemical defenses.

There is some evidence for a relationship between mobility and resistance to seaweed chemical defenses among marine animals. Many small, low-mobility amphipods, polychaetes, ascoglossan gastropods and crabs readily consume seaweeds that produce noxious chemicals which deter feeding by larger, mobile grazers like fishes and urchins (Hay et al. 1987, 1988, 1989, 1990a,b, Stachowicz \& Hay 1996, 1999a). Linited empirical evidence suggests that this pattern may be generalizable to closely-related, similar-sized species that differ in mobility. Among amphipods, for example, low-mobility species are more tolerant of seaweed chemical defenses than higher-mobility species (Duffy \& Hay 1994), and are also better able to substitute food quantity for quality (Cruz-Rivera \& Hay 2000). However, the robustness and generality of this relationship for other groups of marine consumers remains untested. Additionally, the relationship between mobility, selectivity (or breadth of the potential diet) and the ability to engage in compensatory feeding has not been tested using naturally occurring foods. Such investigations may provide insight regarding the barriers to, and constraints on, the evolution of low-mobility lifestyles among marine consumers.

In this study, we examined the relationship between mobility and food choice by 3 species of marine decapod crabs feeding on co-occurring seaweeds in North Carolina: the majid crabs Mithrax forceps and Libinia dubia, and the xanthid Panopeus herbstii. We asked the following questions: (1) Are there differences in mobility among crab species? (2) Are low-mobility species better able to adjust their feeding rate on seaweeds based on organic content (i.e. do they exhibit compensatory feeding?) and (3) Are low-mobility crabs less selective and do they have a broader algal diet than those with greater mobility?

\section{METHODS}

Study organisms. We used 3 decapod, brachyuran crabs of similar size: the majid crabs Mithrax forceps and Libinia dubia, and the xanthid crab Panopeus herbstii. We selected these species based on their abundance and ease of collection near our study sites in North Carolina (USA). Individuals used were representative of sizes found in the habitats where experiments were performed: $M$. forceps: 13 to $25 \mathrm{~mm}$ carapace width; L. dubia: 9 to $23 \mathrm{~mm}$; and $P$. herbstii: 12 to
$28 \mathrm{~mm}$. Crab nomenclature and ecological background is from Williams (1984) unless otherwise noted. $M$. forceps lives on rocky shores and reefs and is commonly found associated with corals and sponges from Brazil to North Carolina. In North Carolina, this crab occurs primarily in a mutualistic association with the coral Oculina arbuscula. The crab consumes coral competitors such as seaweeds and sessile invertebrates, and the coral provides the crab with shelter from predators and with dietary supplements (Stachowicz \& Hay 1999a). L. dubia is found on most types of bottom in sounds and saltier estuaries from southern New England to southern Texas, and also in the Bahamas and Cuba. Juveniles often decorate their carapace with seaweeds or invertebrates, presumably as camouflage against predation. In the southeastern US, L. dubia selectively decorates with the chemically defended brown alga Dictyota menstrualis when this alga is available. In so doing, it behaviorally sequesters the defensive chemistry of this plant for use against its own enemies (Stachowicz \& Hay 1999b). P. herbstii is one of the more common estuarine crabs in North and South Carolina, found wherever the bottom is muddy or covered with shells or stones. The species is common intertidally to $22 \mathrm{~m}$ depth throughout its range from Boston, MA to Santa Catarina, Brazil. For all 3 species, individuals in the size ranges we used readily consume macroalgae as wel.l as animal material in the laboratory (Stachowicz \& Hay 1999a, and unpubl. data).

Unlike terrestrial consumers, there are very few marine organisms that can be considered strictly herbivorous (Karlson 1978, Darcy 1985, Horn 1989), and most crabs are probably best considered omnivorous. Majid and grapsid crabs that are generally regarded as 'herbivorous' have diets comprised of as much as $50 \%$ animal material (Hines 1982, Kennish 1996, Lohrer \& Whitlatch 1997), and 'carnivores' such as the blue crab, Callinectes sapidus consume significant amounts of plant material (Laughlin 1982). Crabs in the genus Mithrax have been reported to be largely herbivorous (Coen 1988a,b, Stachowicz \& Hay 1996), but they will readily consume animal material (Winfree \& Weinstein 1990, J Stachowicz unpubl. data) and actually grow best on an omnivorous diet (Wilber \& Wilber 1989, Stachowicz \& Hay 1999a). Similarly, the diet of Libinia in the field has been described as 'predominantly herbivorous with carnivorous tendencies' on the basis of studies that show that most individuals have guts with more plant than animal material (Ropes 1987). Although adult Panopeus herbstii are often considered carnivores, much of the evidence for this comes from laboratory or controlled field studies that demonstrate these crabs can be voracious predators of commercially important bivalves (e.g. Lee \& Kneib 1994, Micheli 1997 and references cited therein). Gut contents of 
field-captured individuals that are similar in size to those used in our experiments show that xanthids (including members of the genus Panopeus) are omnivorous in the field and frequently consume macroalgae and other plant material when they inhabit areas where it is abundant (Knudsen 1960, Gore et al. 1995, Greenway 1995). Futhermore, direct observations of $P$. herbstii show that these crabs do consume macroalgae in the field (Reames \& Williams 1983). On balance, most evidence suggests that the crabs we used are opportunistic omnivores. The proportion of animal versus plant material in the diet appears to be set, at least in part, by availability.

Crab mobility. We examined the movement patterns of these crabs using mark-recapture techniques in the field. Mithrax forceps were collected from Oculina arbuscula heads at a depth of $9 \mathrm{~m}$, Panopeus herbstil from an intertidal oyster bar, and Libinia dubia from a shallow seagrass bed off the coast of Morehead City, North Carolina. Each crab ( $N=18$ to 20) was marked by super-gluing a small, clear, numbered tag $(4 \mathrm{~mm} \times$ $6 \mathrm{~mm}$, Floy Tag Co., Seattle, WA, USA) to the carapace, and then released in the habitat from which they were collected. The 3 crabs do not co-occur in any 1 habitat type in North Carolina, and because we wanted to measure crab mobility in habitats where they are normally found, we released them in the habitats from which they were collected. The Oculina heads into which $M$. forceps were released formed a nearly continuous thicket at the study site with densities averaging 8 heads $\mathrm{m}^{-2}$, interspersed with lesser amounts of seaweeds, soft corals, hydroids, arborescent bryozoans, and colonial and solitary ascidians (Miller \& Hay 1996, Stachowicz \& Hay 1999a). The seagrass bed into which L. dubia were released was comprised of nearly continuous cover of Halodule wrightii, with drift macroalgae scattered throughout, but averaging around $110 \mathrm{~g} \mathrm{~m}^{-2}$ (J. Stachowicz unpubl. data). The oyster bed into which $P$. herbstii were released was intertidal for $\sim 1$ h of each tidal cycle, and consisted of clumps of live oysters interspersed with shell hash. Some of the oysters had seaweeds or sponges as epibionts, and drift algae was present. Although Panopeus also occurs on subtidal oyster reefs, we could not perform the mark-recapture experiment subtidally because low visibility precluded relocating individual crabs by SCUBA. Additionally, performing this experiment intertidally allowed us to survey this area more intensively by overturning shell clumps to look for crabs. Although these sites differed in the species composition of dominant benthic spaceholders, they resembled each other in that all 3 consisted of roughly rectangular strips of continuous, structurally complex habitat known to offer refuge from predation (Summerson \& Peterson 1984, Meyer 1994, Stachowicz \& Hay 1999a).
Each release point was marked with the tag number of the crab to allow determination of distance traveled from capture to release. After $48 \mathrm{~h}$, we intensively surveyed the area within a $5.0 \mathrm{~m}$ radius of the release point either by hand at low tide (oyster bar, shallow grassbed), or by SCUBA (Oculina heads) to determine (1) the number of individuals of each species that were still located at the release point (site fidelity), and (2) for those crabs we were able to locate, each crab's distance from the release point (mobility). Site fidelity was analyzed by contingency table analysis (chisquare) comparing the frequency of individuals of each species at several distance intervals from the release point: $<10 \mathrm{~cm}, 10$ to $100 \mathrm{~cm}, 100$ to $500 \mathrm{~cm}$, and 'not recovered' (for those individuals that were not found within the $5 \mathrm{~m}$ search area). We analyzed each pair of species separately and adjusted the significance level accordingly using the Dunn-Sidak method (Sokal \& Rohlf 1981).

We estimated species mobility (distance traveled over $48 \mathrm{~h}$ ), in 2 ways. First, we used only those crabs that we were able to relocate. This method likely underestimated mobility, particularly for species that are more mobile, because crabs located close to the release point are more likely to be found than those that are more distant, and those that travel over $5 \mathrm{~m}$ from the release point (i.e. outside our search radius) will never be found. As an alternative to this conservative approach, we included all crabs, and assigned individuals that we did not relocate a distance traveled of $5.0 \mathrm{~m}$. In this analysis, missing crabs are thus assumed to have migrated beyond the $5 \mathrm{~m}$ search area rather than to have been consumed within the $5 \mathrm{~m}$ search area or simply missed during the search. Both Mithrax and Libinia experience very low predation when associated with Oculina and decorated with Dictyota menstrualis, respectively (Stachowicz \& Hay $1999 a, b)$, and in situ predation rates on majids and xanthids appears to be similar (Heck \& Wilson 1987) so we did not expect predation to bias the relative mobility of these species. In absolute terms, this analysis will overestimate mobility if missing crabs are eaten near the release point, but will be overly conservative if most crabs migrate beyond the $5 \mathrm{~m}$ search area. We provide this analysis as a contrast for the conservative nature of the estimate provided by using only recovered crabs. Statistical analyses of mobility were performed using 1-way ANOVA and the Tukey-Kramer method to make comparisons among species.

Diet breadth and compensatory feeding assays. We evaluated the potential breadth of the seaweed portion of the diet for these 3 crabs by measuring crab consumption of the most common subtidal seaweeds found in shallow waters near Morehead City, NC, in both choice and no-choice assays. First, crabs were 
offered a simultaneous choice among the green alga, Ulva rigida, the brown algae Dictyota menstrualis, Dictyota ciliolata, Padina gymnospora, and Sargassum filipendula, and the red algae Chondria dasyphylla, Gracilaria tikvahiae, and Hypnea musciformis. Separate assays measured consumption rates of these same seaweeds when no alternative foods were available; we also measured feeding in these no-choice assays on Gracilaria verrucosa. We placed each crab in a separate $0.5 \mathrm{I}$ bowl that had four $1 \mathrm{~cm}$-diameter holes to allow for flow-through seawater. For choice assays, each bowl with a crab held a 200 to $250 \mathrm{mg}$ piece of each algal species. For no-choice assays, each bowl with a crab held a 500 to $600 \mathrm{mg}$ piece of 1 of the 9 seaweed species. Sample sizes were 10 to $16 \mathrm{crabs}$ of each species for the choice assays, and 7 to 15 crabs of each species per algal species for the no-choice assays. As a control for changes in seaweed mass unrelated to herbivory, identical bowls without crabs contained equivalent pieces of the same individual seaweed. These bowls were paired spatially in our seawater tables. Assays were begun in the late afternoon and terminated 2 mornings later so that each assay lasted $40 \mathrm{~h}$; this duration and timing has been found to be sufficient to measure consumption rates and relative preferences of crabs feeding on seaweeds (Stachowicz \& Hay 1996, 1999a,b). At the end of each assay, each seaweed piece was blotted dry with a paper towel and reweighed. To calculate net mass loss for each algal species due to crab feeding, we corrected for mass changes unrelated to herbivory using the formula $\left[T_{1} \times\left(C_{f} / C_{1}\right)\right]-T_{1}$, where $T_{1}$ and $T_{1}$ were the initial and final masses of the seaweed portion in the container with $a$ crab and $C_{1}$ and $C_{1}$ were the initial and final masses of the seaweed portion in the paired control.

To provide a qualitative assessment of the relative preferences expressed by the 3 crabs, we analyzed the results of choice assays using the non-parametric Friedman test. Additionally, as a quantitative measure of the selectivity of each crab species, we used an index of diet breadth $(B)$ derived by Levins (1968): $B=\left(1 / \Sigma p_{j}{ }^{2}\right)$, where $p_{j}$ is the fraction of the total diet mass represented by item $i$. An index of 1.0 indicates that consumers are highly selective and a single prey type comprises the entire diet, whereas the maximum value of the index occurs at $N$ when each species is represented equally in the diet and $N$ is the total number of choices available ( $N=8$ for our experiments). Differences in diet breadth among crab species were assessed using a 1-way ANOVA, and post-hoc tests were made using the TukeyKramer method. Differences among algal species in organic content and consumption rate in no-choice assays were also assessed using 1-way ANOVA. Data were transformed where necessary prior to analysis to meet the assumptions of ANOVA.
Previously we found that seaweeds that were lowpreference food items for the crab Mithrax sculptus in the Florida Keys (USA) were consumed at the highest rates when no alternative foods were available (Stachowicz \& Hay 1996), and we speculated that this was due to compensatory feeding. We hypothesized that differences in internal anatomy among seaweed species resulted in differences in the water content and corresponding differences in the amount of organic material ingested per unit of alga consumed. Thus, foods of low organic content appeared to be avoided by this crab when alternatives were available, but were consumed at high rates when alternatives were unavailable in order to meet intake requirements. We evaluated this hypothesis more rigorously for Mithrax forceps, Libinia dubia and Panopeus herbstii feeding on seaweeds from North Carolina by comparing feeding rates in choice and no-choice assays with the percent organic content (ash-free dry mass / wet mass) of each algal species. We used organic content for our measure of food quality because it allowed us to evaluate the generality of our previous results by quantifying the amount of plant material consumed per unit wet mass of food. No measure of the quality of algal diets has been consistently correlated with consumer preference or performance, including protein and total nitrogen (Carefoot 1967, Nicotri 1980, Robertson \& Lucas 1983, Duffy \& Hay 1991, Cronin \& Hay 1996a), so we did not measure these factors. While the presence of noxious chemicals does consistently affect feeding by many marine consumers (review in Hay 1996), here we tested whether consumers can compensate despite the presence of possible chemical defenses.

Ash-free dry mass (AFDM) per unit wet mass (organic content) was obtained for each algal species offered in no-choice assays. Wet mass was obtained by weighing a piece of the alga after it had been blotted dry with a paper towel. AFDM was calculated as the difference between the dry mass of that same piece of alga (after drying in an oven at $65^{\circ} \mathrm{C}$ for $48 \mathrm{~h}$ ) and the ash mass (after combusting at $500^{\circ} \mathrm{C}$ for $24 \mathrm{~h}$ ). Determinations of organic content were made for 5 individual plants of each species. The strength of the association between the mean organic content of each algal species and the mean amount of that alga consumed in the no-choice assays by each crab species was assessed using Spearman's rank correlation procedure.

\section{RESULTS}

\section{Crab mobility}

Mithrax forceps exhibited the greatest site fidelity and lowest mobility of the species tested. In the contin- 
gency table analysis, $M$. forceps exhibited greater site fidelity than either Libinia dubia or Panopeus herbstii (Fig. 1A, $\chi^{2}=28.5$ and 31.0, respectively; $\mathrm{p}<0.0001$ for both), as 16 of the 18 $M$. forceps were relocated within $10 \mathrm{~cm}$ of the point of release $48 \mathrm{~h}$ later. Because no individuals of $L$. dubia or $P$. herbstii were relocated within $10 \mathrm{~cm}$ of the release point, we combined the $<10 \mathrm{~cm}$ and the 10 to $100 \mathrm{~cm}$ distance categories for the comparison between $L$. dubia and P. herbstii. In this analysis, $L$. dubia appeared to be more site-attached than $P$. herbstii, as a large number of the latter species ( 14 of 20 ) were not relocated within the $5.0 \mathrm{~m}$ search range (Fig. $1 \mathrm{~A}, \chi^{2}=8.26$, $p=0.016$; because of corrections due to multiple tests, a p-value of 0.017 is required for statistical confidence at the $\alpha=0.05$ level). Because all $M$. forceps that were recovered were found on the same corals on which they were released, mobility using only recovered crabs for this species was zero, significantly less than that of both $L$. dubia and $P$. herbstii, which did not differ from each other by this measure (Fig. 1B, p $<0.0001$, 1 -way ANOVA, Tukey-Kramer multiple comparisons at $\alpha=0.05$ ). However, when non-recovered crabs were assigned a mobility equal to the search radius of $5 \mathrm{~m}, L$. dubia mobility was less than that of P. herbstii (Fig. 1C, $\mathrm{p}<0.05$, TukeyKramer multiple comparisons), while $M$. forceps mobility was still lower than that of $L$. dubia or $P$. herbstii, (Fig. 1C, $\mathrm{p}<0.01$, Tukey-Kramer multiple comparisons).

\section{Selection among algal species}

Mithrax forceps generally exhibited only weak preferences among seaweeds, whereas Libinia dubia and Panopeus herbstii strongly avoided several species of brown algae, such as Dictyota menstrualis, Dictyota ciliolata and Sargassum filipendula. P. herbstii and L. dubia consumed primarily red and green seaweeds like Ulva and Gracilaria tikvahiae (Fig. 2B,C), with $L$. dubia also consuming significant amounts of Hypnea, Chondria and Padina. M. forceps consumed $D$. menstrualis significantly more than all other species with the exception of Chondria dasyphylla (Fig. $2 \mathrm{~A}, \mathrm{p}<0.05$ ). As a result of these strong differences in feeding preferences among crab species, selectivity $(B)$ differed among the 3 species $(p<$ $0.0001,1$-way ANOVA, Fig. 3) and appeared to be negatively correlated with site fidelity and one of our mobility estimates. The least mobile and most siteattached crab, $M$. forceps, had the broadest, least selective diet, whereas $L$. dubia was intermediate in
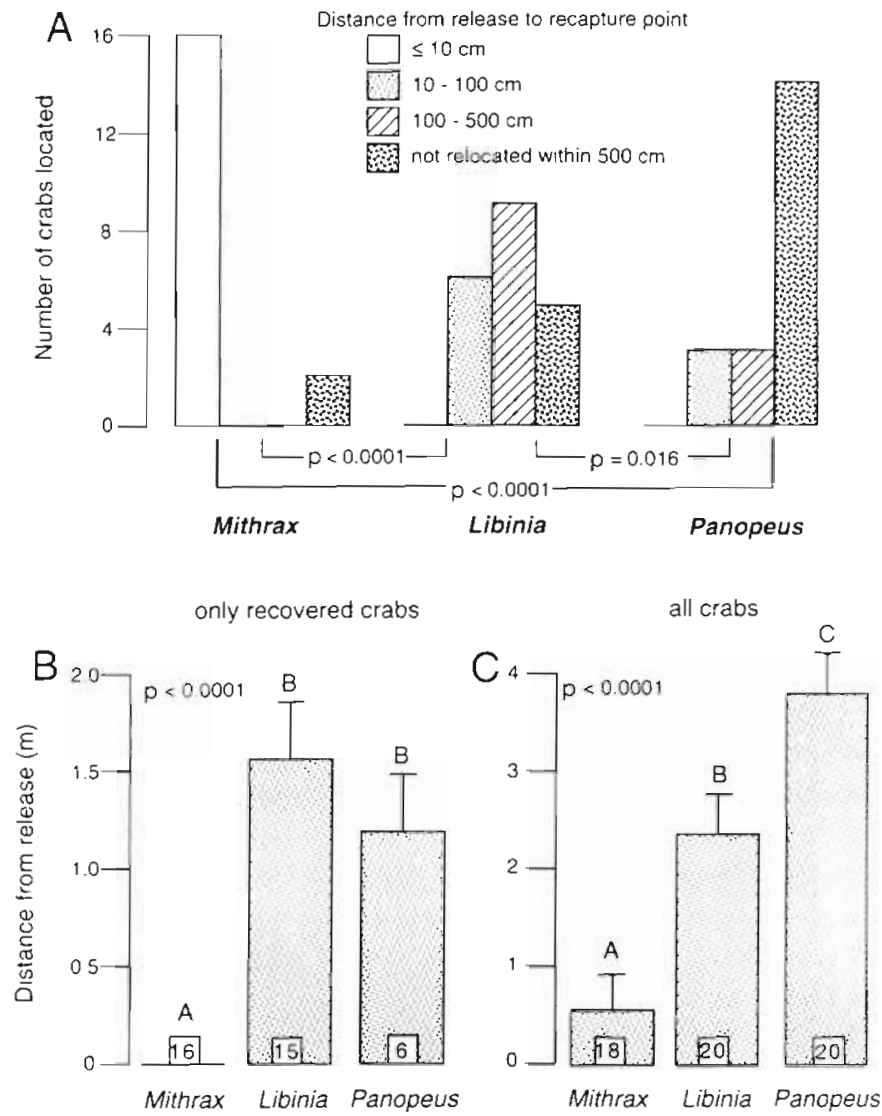

Fig. 1. (A) Site fidelity and (B \& C) Mobility of 3 species of decapod crabs. No. of crabs released: 18 for Mithrax forceps, 20 for Libinia dubia and 20 for Panopeus herbstii. Statistical tests for differences in (A) site fidelity are by multiple contingency-table analyses with p-values indicated on the figure. Because multiple tests were performed, the p-value required for statistical confidence at the $95 \%$ level is $p=0.017$. Mobility estimates are derived by either (B) considering only distance traveled for crabs actually recovered or by (C) assigning all non-recovered crabs a distance traveled equal to the search radius of $5.0 \mathrm{~m}$. (See 'Methods' for a fuller description and rationale for each procedure.) Statistical testing for mobility differences among species was by 1 -way ANOVA with the Tukey-Kramer multiple comparisons procedure $(p<0.05)$

both selectivity and mobility, and $P$. herbstii had the narrowest diet and lowest site-fidelity (Fig. $3, p<0.05$. Tukey-Kramer Post-Hoc tests).

\section{Compensatory feeding - no choice assays}

Feeding rates in no-choice assays were positively correlated with preferences in choice assays for Panopeus herbstii and Libinia dubia (Spearman rank correlation test $\mathrm{p}=0.049$ and $\mathrm{p}=0.009$, respectively), but not for Mithrax forceps ( $p=0.173)$. When no alternatives were available, all species consumed Gracilaria tikvahiae most heavily, and this species had the lowest ash-free dry mass per wet mass of any of the 
seaweeds tested (Fig. 4, 1-way ANOVAs with TukeyKramer multiple comparisons at $\alpha=0.05$ ). However, both $L$. dubia and $P$. herbstii consumed large amounts of Ulva, the seaweed with the highest organic content, while $M$. forceps consumed this plant the least (Fig. 4). Additionally, $L$. dubia and $P$. herbstii avolded consuming Dictyota ciliolata or Dictyota menstrualls, and P. herbstii also avoided consuming Sargassum or Chondria (Fig. 4). Thus there was a significant negative correlation between the organic content of a given seaweed and the amount of that seaweed consumed in a no-choice assay for $M$. forceps ( $p=0.009, F 1 g .5 A$ ), but
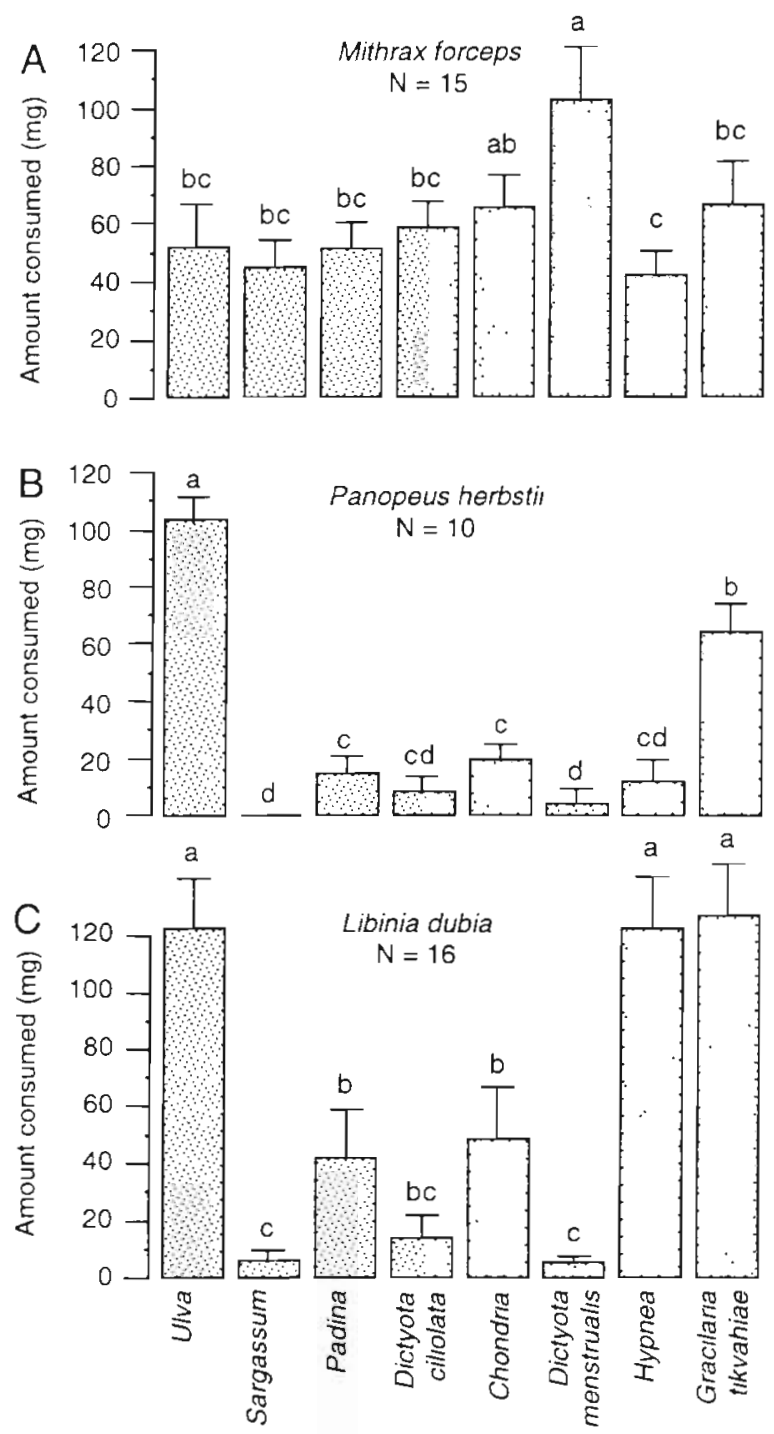

Fig. 2. Selection of seaweeds as food by (A) Mithrax forceps, (B) Panopeus herbstii, and (C) Libinia dubia Crabs were offered a simultaneous choice of 8 species of seaweed and were allowed to feed for $40 \mathrm{~h}$. Statistical analysis is by the non-pardmetric Friedman's test; different letters over each bar indicate differences in amount consumed $(\mathrm{p}<005$, see 'Results' for detalls)

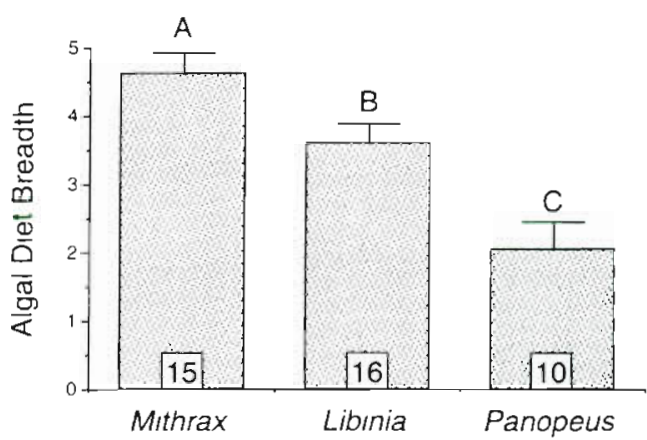

Fig 3 Levins' (1968) index of diet breadth of each crab as assessed by multı-choice lab experuments (see 'Methods' for detaıls). A completely non-selective crab that consumed all species of seaweed equally would have an index value of 8 , whereas a crab that fed exclusively on a single species would have an index value of 1 . Thus, larger index values indicate a broader (less selective) diet. Statistics are by 1 -way ANOVA with significant differences among species indicated by different letters above each bar (Tukey-Kramer multiple compansons procedure $p<005$ )

not for P. herbstii $(\mathrm{p}=0.332$, Fig. 5B) or $L$. dubia $(\mathrm{p}=$ 0.368 , Fig. $5 C$ ) Only $M$. forceps, the crab with the lowest mobility and highest site fidelity appears to consistently compensate for the low organic content of a seaweed by consuming greater quantities.

\section{DISCUSSION}

Our results suggest that low mobllity among manne crabs is associated with compensatory feeding and a broad seaweed diet with little selection among species (Table 1). Although there may be negative impacts on growth and fitness associated with chronic consumptıon of low quality diets (Cruz-Rivera \& Hay 2000), Mithrax forceps can at least behaviorally compensate for the low nutntional value of some seaweeds by increasing consumption rates when confined with these species (Fig. 5). M. forceps can compensate because it readily consumed all of the seaweeds offered in no-choice assays whereas Libinia dubia and Panopeus herbstu consistently avolded consuming most

Table 1 Summary of mobility and diet charactenstics for Mithrax forceps, Libinia dubia, and Panopeus herbstu

\begin{tabular}{|lccc|}
\hline & M. torceps & L. dubia & P. herbstu \\
\hline $\begin{array}{l}\text { Mobllty } \\
\text { Compensatory feeding }\end{array}$ & Yow & Moderate & Moderate/high \\
$\begin{array}{l}\text { Algal diet breadth } \\
\text { Resistant to }\end{array}$ & Broad & Intermediate & Narrow \\
chemical defense?a & Yes & No2 & No \\
afrom Stachowicz \& Hay (1999a) & & \\
\hline
\end{tabular}


species of brown algae (Figs. 2 \& 4). In this regard, both $L$. dubia and $P$. herbstii behave similarly to local species of fishes and sea urchins considered to be herbivorous or omnivorous, as these species consume only
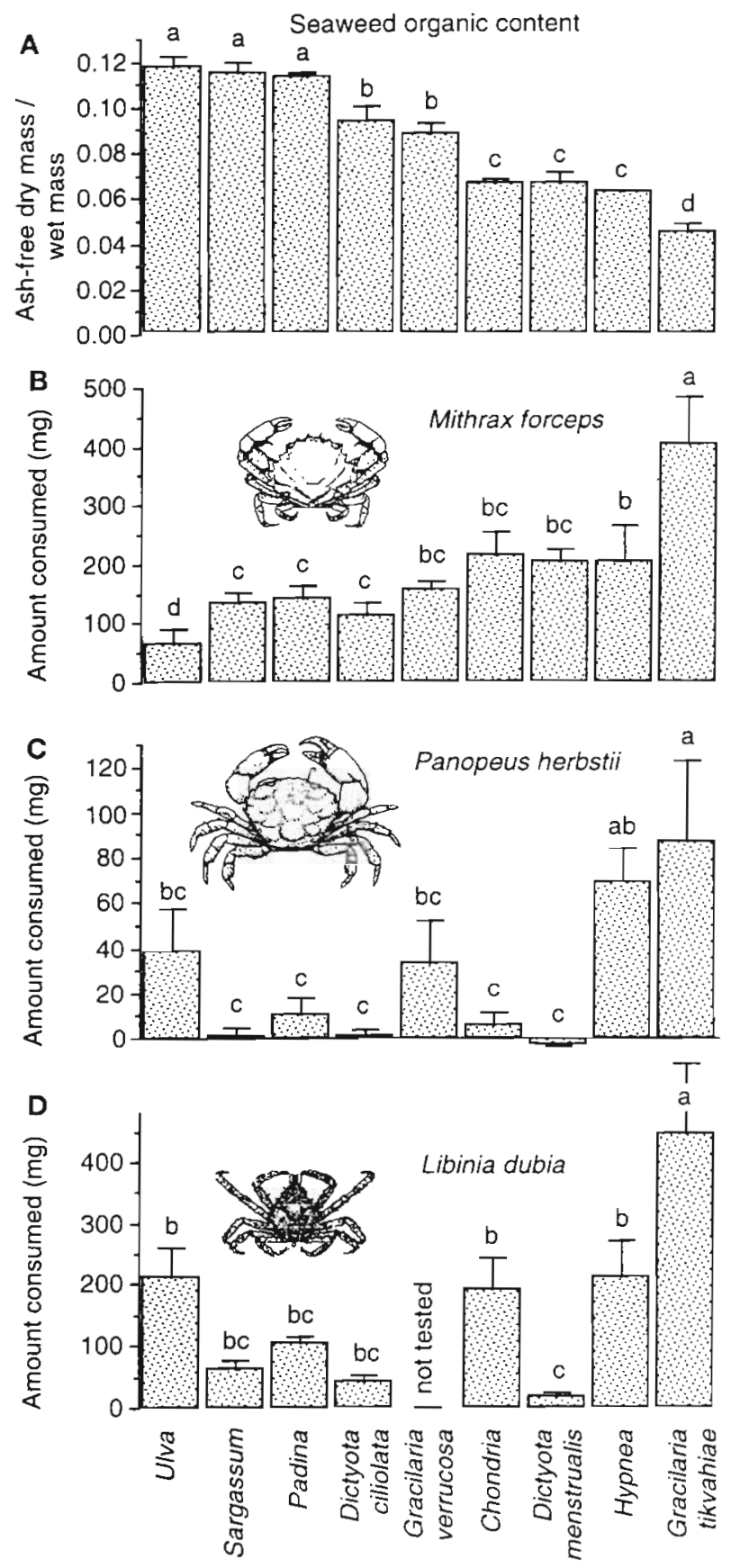

Fig. 4. (A) Organic content and consumption of seaweeds by (B) Mithrax forceps, (C) Libinia dubia and (D) Panopeus herbstii. Sample sizes for each crab-seaweed combination range from 7 to 15. Statistical analysis of feeding rate for each crab and seaweed organic concentration is by 1 -way ANOVA with significant differences among seaweed species indicated by different letters above each bar (Tukey-Kramer multiple comparisons procedure $p<0.05$ ) selected red and green algae and generally avoid brown algae altogether (Hay et al. 1987, 1988, Stachowicz \& Hay 1999a).

Avoidance of brown algae by many grazers appears to be related to chemical defenses produced by these seaweeds (Hay et al. 1987, 1988, Cronin \& Hay 1996b. Stachowicz \& Hay 1999a). Extracts from Dictyota menstrualis and Dictyota ciliolata deter feeding by Panopeus herbstii but not by Mithrax forceps (Stachowicz \& Hay 1999a). Although the effects of seaweed defensive chemistry on Libinia dubia are unknown, this crab avoided consuming these chemically-rich algae (Fig. 2) even when no other choices were available (Fig. 4). This suggests that these algae may be chemically defended from $L$. dubia. Thus, low mobility is also associated with resistance to chemical defenses. The ability

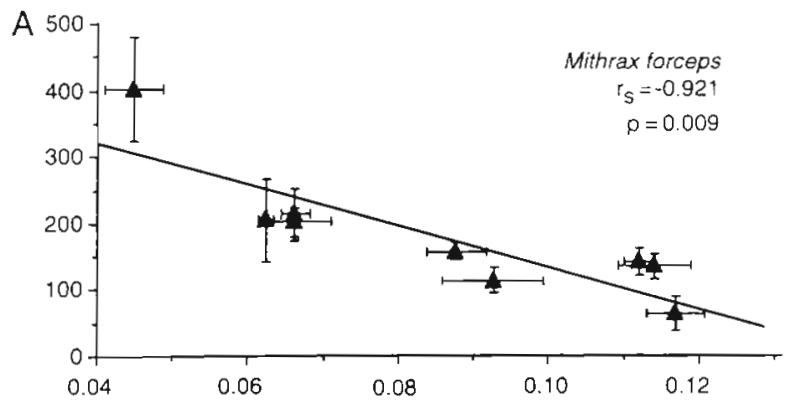

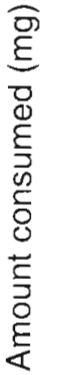
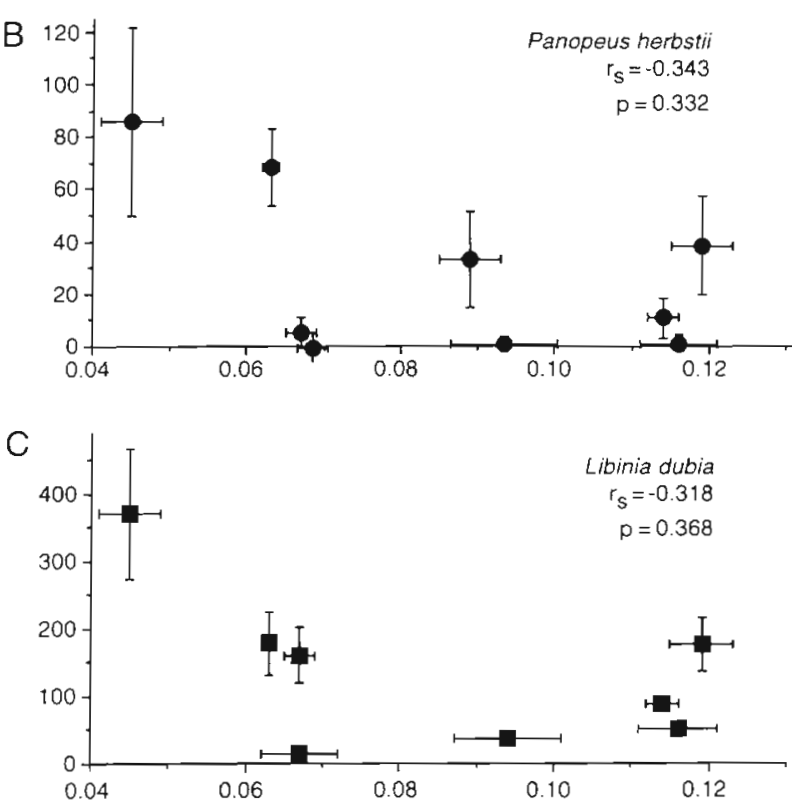

Ash-free dry mass / wet mass

Fig. 5. Feeding rate versus seaweed organic content for (A) Mithrax forceps, (B) Libinia dubia and (C) Panopeus herbstii. Data points are means $\pm 1 \mathrm{SE}$. Correlation between the seaweed consumption rates for each crab species and the organic content of that seaweed species was assessed by the Spearman rank procedure. $\mathrm{p}$-values are given on each figure 
of $M$. forceps to exhibit true compensation may be a consequence of its resistance to, or tolerance of, seaweed defensive metabolites. This may be a common feature of low-mobility grazers, as reduced mobility among amphipods is also associated with tolerance of seaweed secondary metabolites (Duffy \& Hay 1994) and compensatory feeding on artificial foods (CruzRivera \& Hay 2000).

Additional measures of nutritional quality, such as protein content, do not appear to help further explain preferences and consumption rates among these crabs. For example, protein concentrations are twice as high in Dictyota menstrualis as they are in Hypnea and Chondria (Duffy \& Hay 1991), yet Mithrax forceps consumed all 3 of these species at equal rates in no-choice assays (Fig. 4). The low rates of feeding by Libinia dubia on higher-protein brown algae such as Sargassum and $D$. menstrualis relative to algae with lower protein content like Chondria and Hypnea (Duffy \& Hay 1991) in no-choice assays (Fig. 4) might be construed as compensatory feeding in response to protein concentrations. However, these brown algae are strongly avoided when these crabs are provided with alternative algae (Fig. 2), suggesting that low feeding rates in no-choice assays are due to the chemical unpalatability of these species rather than satiation. As in several previous studies (Carefoot 1967, Nicotri 1980, Robertson \& Lucas 1983, Duffy \& Hay 1991. Cronin \& Hay 1996a), we saw no consistent correlation between nitrogen or protein levels and consumer preferences among, or feeding rates on, marine algae.

We are confident in our field-based mobility estimates, because (1) they assess mobility and site fidelity of these crabs in their natural environment; and (2) they are consistent with previous reports of high site-fidelity in Mithrax species (Hazlett \& Rittschof 1975), and lower site-fidelity in Panopeus herbstij (Lee \& Kneib 1994). However, our data only point out an association between mobility and diet parameters and do not demonstrate causation. Male and female crabs of many species have different mobilities that are related to mating behaviors (Wirtz \& Diesel 1983, Lindberg \& Stanton 1989, Lindberg et al. 1990), but these cannot explain the differences we observed in mobility between species. The high sitefidelity observed in some crabs is tied to brooding or guarding of juvenile stages (Diesel 1989, Diesel \& Horst 1995) or mates (Lindberg \& Stanton 1989). Conversely, high adult mobility and low site-fidelity may be required for species that migrate among habitats, as do semiterrestrial crabs that live on dry land but release larvae directly into the sea (Diesel \& Schuh 1998 and references cited therein). Regardless of what ultimately determines mobility, it seems likely that any constraints placed on patterns of movement could profoundly influence feeding behavior and risk of predation.
Reduced mobility decreases predation risk in a wide variety of animals (e.g. Sih 1987, Duffy \& Hay 1994); however, reduced mobility also limits the prey choices available for consumption, limiting the animal to nearby foods. Thus, a low mobility species like Mithrax forceps, which is too large to inhabit the plants it consumes, has a broad, low-selectivity diet (Fig. 2A) and can compensate for low food quality by increasing intake (Figs. 4 \& 5A). Having these diet characteristics may further reduce the amount of movement required to meet dietary needs, and decrease predation risk by maximizing the amount of time the crab can spend near a refuge. This low-selectivity diet gives these crabs the potential to locally reduce seaweed biomass, whereas more selective grazers typically alter only the species composition of the algal community (Miller \& Hay 1996). Because of their low mobility, the feeding activities of these animals are concentrated around their shelter. When this shelter is comprised of a living organism such as a coral or calcified seaweed, lowmobility consumers may benefit their host by removing epiphytes or encroaching competitors (Coen 1988a, Littler et al. 1995, Stachowicz \& Hay 1996, 1999a). Interestingly, the refuge that is derived from the camouflage behavior typical of decorator crabs (Wicksten 1980, Stachowicz \& Hay 1999b) may facilitate increased mobility because the 'shelter' is portable. Although decorator crabs move slowly to avoid detection, even the small increase in mobility observed in Libinia dubia relative to Mithrax forceps (Fig. 1) may permit this crab to encounter a greater diversity of prey more reliably, and safely, facilitating the observed increase in selectivity in seaweed consumption (Figs. $2 \& 3$ ).

\section{Caveats and conclusions}

Although all 3 crabs we used are brachyuran crabs, the splitting of the majid family from the rest of the brachyurans is apparently ancient, and subfamilial phylogenetic relationships within the majidae are unclear (Rice 1983). Thus, in our study, as in much of comparative biology, it is difficult to determine whether present traits are a consequence of current selection pressures or are relics of ancient splitting events. However, given that the relationship between low mobility, compensatory feeding and consumer resistance to algal chemical defenses appears to hold among species within a family (majidae), as well as between families (majid vs. xanthid), and that our results are consistent with previous comparisons (Hay et al. 1987, 1988, Duffy \& Hay 1994, Cruz-Rivera \& Hay 2000 ), this association appears to be robust.

Any trait that facilitates reduced mobility can be of considerable advantage to marine invertebrates in- 
habiting shallow water coastal communities where predation is intense, because it allows them to maximize the amount of time they spend in refuges. In many cases these predator refuges are sessile plants or animals that physically or chemically exclude larger omnivores that prey on small invertebrates like crabs (Coen 1988a, Hay 1992, Hay \& Fenical 1996, Stachowicz \& Hay 1996, 1999a, b). The broad diet of these low-mobility animals has important system-wide consequences, because it allows these consumers to facilitate the growth and survival of their hosts, which are often important producers of biogenic habitat for a variety of species (Littler et al. 1995, Stachowicz \& Hay 1999a). In addition, the activities of these grazers can create mosaics of algal density and productivity (Branch et al. 1992, Stachowicz \& Hay 1999a), which can directly alter the outcome of competitive interactions among seaweeds (Bertness \& Leonard 1997) and decrease recruitment of fishes and invertebrates (Dean \& Connell 1987, Levin \& Hay 1996). Thus, although the impact of small, non-selective grazers may be spatially limited, this type of grazing clearly merits consideration in models of grazer impact on ecosystem dynamics.

Acknowledgements. The work was supported by the National Science Foundation through NSF grant OCE 95-29784 to M.H. and a doctoral fellowship to J.J.S., and by a dissertation fellowship from the Graduate School of the University of North Carolina at Chapel Hill to J.J.S. We thank J. Pawlik for editorial assistance and 3 anonymous reviewers for comments on a previous draft of the manuscript.

\section{LITERATURE CITED}

Bertness MD, Leonard GH (1997) The role of positive interactions in communities: lessons from intertidal environments. Ecology 78:1976-1989

Branch GM, Harris JM, Parkins C, Bustamante RH, Eekhout S (1992) Algal 'gardening' by grazers: a comparison of the ecological effects of territorial fish and limpets. In: John DM. Hawkins SJ, Price JH (eds) Plant-animal interactions in the Marine Benthos. Systematics Association Special Volume 46, Clarendon Press, Oxford, p 405-423

Carefoot TH (1967) Growth and nutrition of Aplysia punctulata feeding on a variety of marine algae. J Mar Biol Assoc UK 47:565-589

Coen LD (1988a) Herbivory by crabs and the control of algal epibionts on Caribbean host corals. Oecologia 75:198-203

Coen LD (1988b) Herbivory by Caribbean Majid crabs: feeding ecology and plant susceptibility. J Exp Mar Biol Ecol 122:257-276

Cronin G, Hay ME (1996a) Induction of seaweed chemical defenses by amphipod grazing. Ecology 77:2287-2301

Cronin G, Hay ME (1996b) Susceptibility to herbivores depends on the recent history of both the plant and the animal. Ecology 77:1531-1543

Cruz-Rivera E, Hay ME (2000) Can quantity replace quality? Food choice, compensatory feeding, and fitness of marine mesograzers. Ecology 81(1):in press
Darcy GH (1985) Synopsis of biological data on the pinfish, Lagodon rhomboides (Pisces: Sparidae). NOAA. Tech Rep. Nat Mar Fish Serv Circ 19

Dean RL, Connell JH (1987) Marine invertebrates in algal succession. II. Tests of hypotheses to explain changes in diversity with succession. J Exp Mar Biol Ecol 109 $217-247$

Diesel R (1989) Parental care in an unusual environment: Metopaulias depressus (Decapoda, Grapsidae), a crab that lives in epiphytic bromeliads. Anim Behav 38:561-575

Diesel R, Horst D (1995) Breeding in a snail shell: ecology and biology of the Jamaican montane crab Sesarma jarvisi (Decapoda: Grapsidae). J Crustac Biol 15:179-95

Diesel R. Schuh M (1998) Effects of salinity and starvation on larval development of the crabs Armases ricardi and $A$. roberti (Decapoda: Grapsidae) from Jamaica with notes on the biology and ecology of adults. J Crustacean Biol 18 : $423-436$

Duffy JE, Hay ME (1991) Food and shelter as determinants of food choice by an herbivorous marine amphipod. Ecology $72: 1.286-1298$

Duffy JE, Hay ME (1994) Herbivore resistance to seaweed chemical defense: the roles of mobility and predator risk. Ecology 75:1304-1319

Faulkner DJ (1992) Chemical defenses of marine mollusks. In: Paul VJ (ed) Ecological roles of marine natural products. Comstock, Ithaca, New York, p 119-164

Gore RH, Sotto LE, Becker LJ (1995) Community composition, stability, and trophic partitioning in decapod crustaceans inhabiting some subtropical sabellarid worm reefs. Studies on decapod crustaceans from the Indian River region of Florida. Buil Mar Sci 28:221-248

Greenway M (1995) Trophic relationships within a Jamaican seagrass meadow and the role of the echinoid Lytechinus variegatus (Lamarck). Bull Mar Sci 56:719-736

Hay ME (1992) The role of seaweed chemical defenses in the evolution of feeding specialization and in the mediation of complex interactions. In: Paul VJ (ed) Ecological roles of marine natural products. Comstock, Ithaca, NY, p 93-118

Hay ME (1996) Marine chemical ecology: what's known and what's next? J Exp Mar Biol Ecol 200:103-134

Hay ME, Fenical W (1996) Chemical ecology and marine biodiversity: insights and products from the sea. Oceanography 9:10-20

Hay ME, Duffy JE, Pfister CA, Fenical W (1987) Chemical defenses against different marine herbivores: are amphipods insect equivalents? Ecology 68:1567-1580

Hay ME, Renaud PE, Fenical W (1988) Large mobile versus small sedentary herbivores and their resistance to seaweed chemical defenses. Oecologia 75:246-252

Hay ME, Pawlik JR, Duffy JE, Fenical W (1989) Seaweed-herbivore-predator interactions: host specialization reduces predation on small herbivores. Oecologia 81:418-427

Hay ME, Duffy JE, Fenical W (1990a) Host-plant specialization decreases predation on a marine amphipod: an herbivore in plant's clothing. Ecology 71:733-743

Hay ME, Duffy JE, Paul VJ, Renaud PE, Fenical W (1990b) Specialist herbivores reduce their susceptibility to predation by feeding on the chemically-defended seaweed Avrainvillea longicaulis. Limnol Oceanogr 35: $1734-1743$

Hazlett B, Rittschof D (1975) Daily movements and home range in Mithrax spinosissimus (Majidae, Decapoda). Mar Behav Physiol 3:101-118

Heck KL Jr, Wilson KA (1987) Predation rates on decapod crustaceans in Iatitudinally separated seagrass communi- 
ties: a study of spatial and temporal variation using tethering techniques. J Exp Mar Biol Ecol 107:87-100

Hines A.H (1982) Coexistence in a kelp forest: size, population dynamics, and resource partitioning in a guild of spider crabs (Brachyura, Majidae). Ecol Monogr 52:179-198

Horn MH (1989) Biology of marine herbivorous fishes. Oceanogr Mar Biol Annu Rev 27:167-272

Karlson RH (1978) Predation and space utilization patterns in a marine epifaunal community. J Exp Mar Biol Ecol 31: $225-239$

Kennish R (1996) Diet composition influences the fitness of the herbivorous crab Grapsus albolineatus. Oecologia 105: $22-29$

Knudsen JW (1960) Aspects of the ecology of the California pebble crabs (Crustacea: Xanthidae). Ecol Monogr 30: 165-185

Laughlin RA (1982) Feeding habits of the blue crab, Callinectes sapidus Rathbun, in the Apalachicola estuary, Florida. Bull Mar Sci 32:807-822

Lee SY, Kneib RT (1994) Effects of biogenic structure on prey consumption by the xanthid crabs Eurytium limosum and Panopeus herbstii in a salt marsh. Mar Ecol Progr Ser 104: $39-47$

Levin PS, Hay ME (1996) Responses of temperate reef fishes to alterations in algal structure and species composition. Mar Ecol Prog Ser 134:37-47

Levins R (1968) Evolution in changing environments: some theoretical explorations. Princeton University Press, New Jersey

Lindberg WJ, Stanton GR (1989) Resource quality, dispersion and mating prospects for crabs occupying bryozoan colonies. J Exp Mar Biol Ecol 128:257-282

Lindberg WJ, Fraser TK, Stanton GR (1990) Population effects of refuge dispersion for adult stone crabs (Xanthidae, Menippel Mar Ecol Prog Ser 66:239-249

Littler MM, Littler DS, Taylor PR (1995) Selective herbivore increases the biomass of its prey: a chiton-coralline reef building association. Ecology 76:1666-1681

Lohrer AM, Whitlatch RB (1997) Ecological studies on the recently introduced Japanese shore crab (Hemigrapsus sanguineus), in Eastern Long Island Sound. In: Balcom NC (ed) Proceedings of the Second Northeast Conference on Nonindiginous Aquatic Nuisance Species. Ct Sea Grant Coll Prog Pub CTSC-97-02, p 49-60

Meyer, DL (1994) Habitat partitioning between the xanthid crabs Panopeus herbstii and Eurypanopeus depressus on intertidal oyster reefs (Crassostrea virginica) in southeastern North Carolina. Estuaries 17:674-679

Micheli $F$ (1997) Effects of experience on crab foraging in a mobile and a sedentary species. Anim Behav 53:1149-1159

Miller MW, Hay ME (1996) Coral-seaweed-grazer-nutrient interactions on temperate reefs. Ecol Monogr 66:323-344

Nelson WG (1979) An analysis of structural pattern in an eelgrass (Zostera marina L.) amphipod community. J Exp Mar Biol Ecol 39:231-264

Nicotri ME (1980) Factors involved in herbivore food preference. J Exp Mar Biol Ecol 42:13-26

Editorial responsibility: Joseph Pawlik (Contributing Editor), Wilmington, North Carolina, USA
Pennings SC (1990) Multiple factors promoting narrow host range in the sea hare, Aplysia californica. Oecologia 82: $192-200$

Randall JE (1967) Food habits of reef fishes of the West Indies. Stud Trop Oceanogr 5:665-847

Reames RC, Williams AB (1983) Mud crabs of the Panopeus herbstii H.M. Edw., S.L., complex in Alabama, USA. Fish Bull 81:885-90

Rice AL (1983) Zoeal evidence for brachyuran phylogeny. In: Schram FR (ed), Crustacean issues 1: Crustacean phylogeny. AA Balkema, Rotterdam, p 313-329

Robertson AI, Lucas JS (1983) Food choice, feeding rates, and the turnover of macrophyte biomass by a surf-zone inhabiting amphipod. J Exp Mar Biol Ecol 72:99-124

Ropes JW (1987) The food habits of five crab species at Pettaquamscutt River, RI. Fish Bull 87:197-204

Sih A (1987) Predators and prey lifestyles: an evolutionary and ecological overview. In: Kerfoot WC, Sih A (eds) Predation: direct and indirect impacts on aquatic communities. University Press of New England, Hanover, NH, p 203-224

Sokal RR, Rohlf FJ (1981) Biometry, 2nd edition. W. H. Freeman and Company, New York

Stachowicz JJ, Hay ME (1996) Facultative mutualism between an herbivorous crab and a coralline alga: advantages of eating noxious seaweeds. Oecologia 105:377-387

Stachowicz JJ, Hay ME (1999a) Mutualism and coral persistence: the role of herbivore resistance to algal chemical defense. Ecology 80:2085-2101

Stachowicz JJ, Hay ME (1999b) Reducing predation through chemically-mediated camouflage: indirect effects of plant defenses on herbivores. Ecology 80:495-509

Steneck RS (1982) A limpet-coralline alga association: adaptations and defenses between a selective herbivore and its prey. Ecology 63:507-522

Stoner AW (1979) Species-specific predation on amphipod crustacea by the pinfish Lagodon rhomboides: mediation by macrophyte standing crop. Mar Biol 55:201-207

Summerson HC, Peterson CH (1984) Role of predation in organizing benthic communities of a temperate-zone seagrass bed. Mar Ecol Prog Ser 15:63-77

van Dolah RF (1978) Factors regulating the distribution and population dynamics of the amphipod Gammarus palustris in an intertidal salt marsh community. Ecol Monogr 48: $191-217$

Wicksten MK (1980) Decorator crabs. Sci Am 242:146-154

Wilber DH, Wilber TP Jr (1989) The effects of holding space and diet on the growth of the West Indian spider crab Mithrax spinosissimus (Lamarck). J Exp Mar Biol Ecol 131: 215-222

Williams AB (1984) Shrimps, lobsters and crabs of the Atlantic coast. Smithsonian, Washington DC

Winfree RA, Weinstein S (1990) Food habits of the Caribbean king crab Mithrax spinosissimus (Lamarck). Proc Gulf Caribbean Fish Inst 39:458-464

Wirtz P, Diesel R (1983) The social structure of Inachus phalangium, a spider crab associated with the sea anemone Anemonia sulcata. Z Tierpsychologie 62:209-234

Submitted: December 28, 1998; Accepted: June 9, 1999

Proofs received from author(s): October 25, 1999 